\title{
Managing the spread of pathogens and aquatic invasive species in the Great Lakes recreational fishery: An application of the drivers-pressures-state-impacts- responses framework
}

\author{
Nadine Heck ${ }^{a, b},{ }^{*}$, T. Bruce Lauber ${ }^{b}$, Richard C. Stedman ${ }^{b}$ \\ a Institute of Marine Sciences, University of California, Santa Cruz, 1156 High Street, \\ Santa Cruz, CA, 95064, USA \\ b Department of Natural Resources, Cornell University, Ithaca, NY, 14850, USA \\ * Corresponding author. Institute of Marine Sciences, University of California, Santa Cruz, \\ 1156 High Street, Santa Cruz, CA, 95064, USA. E-mail address: nheck@ucsc.edu (N. Heck).
}

\section{Abstract}

The Great Lakes are one of the most invaded aquatic ecosystems in the world, and the spread of fish pathogens and aquatic invasive species (AIS) has become a serious issue for fishery management in the Great Lakes. Our study applies the Drivers-Pressures-State-ImpactsResponses model (DPSIR) to identify social-ecological linkages in the spread of pathogens and AIS by anglers, boaters, and bait dealers in the Great Lakes. We developed a conceptual DPSIR model based on input by staff members in governmental agencies and non-governmental organizations that have been involved in the management of pathogens and AIS. The integration of managers' input to develop the model is a novel approach for understanding fisheries. Most previous studies using the DPSIR framework did not account for natural resource managers' input even though the DPSIR framework is frequently applied to provide information to these groups. The identified relationships in our model provide multiple entry points for empirical, interdisciplinary research. These studies would help understand the effectiveness of management responses to change human behaviors, and to understand and predict changes in the Great Lakes ecosystem and fishery. The model could also be used to promote understanding of the impacts of pathogens and AIS on the fishery, and to increase awareness of human behaviors that contribute to the continued spread. Future studies could further expand or replicate the model with input by other stakeholder groups such as bait dealers and/or anglers and boaters to identify if these groups share an understanding of the management problem and responses. 
This is the accepted manuscript of a paper published in Ocean \& Coastal Management. The final version is accessible at https://doi.org/10.1016/j.ocecoaman.2016.08.007.

\section{Introduction}

The spread of pathogens and invasive species has become a major driver of biodiversity loss and global ecological and evolutionary change (Sala et al., 2000; Myers and Knoll, 2001; Olden et al., 2004; Lodge et al., 2006; Anderson et al., 2014). Freshwater systems in particular are highly susceptible to the introduction of pathogens and aquatic invasive species (AIS) as they are exposed to multiple pathways of introduction such as ballast water exchange, the release of alien plant and animal species, or the construction of canals (e.g. Rahel, 2007; Strayer and Findlay, 2010; Oidtmann et al., 2011; Kelly et al., 2013). The fluid nature of aquatic ecosystems further contributes to dispersal and movement of pathogens and AIS once they have been introduced (Vanderploeg et al., 2002; Jacobs and Macisaac, 2007; Rahel, 2007; Kelly et al., 2013).

Our study investigates the management of pathogens and AIS in the Great Lakes, which are one of the most invaded aquatic ecosystems in the world (Ricciardi, 2006). The Great Lakes basin consists of five connected lakes (Superior, Huron, Michigan, Erie, and Ontario) that make up the largest surface freshwater system in the world (EPA 2014) (Fig. 1). Multiple agencies across the basin are involved in the management of pathogens and AIS and the fishery in the lakes including federal, state, and provincial government agencies, and tribal authorities/First Nations in the US and Canada (Gaden et al., 2012).

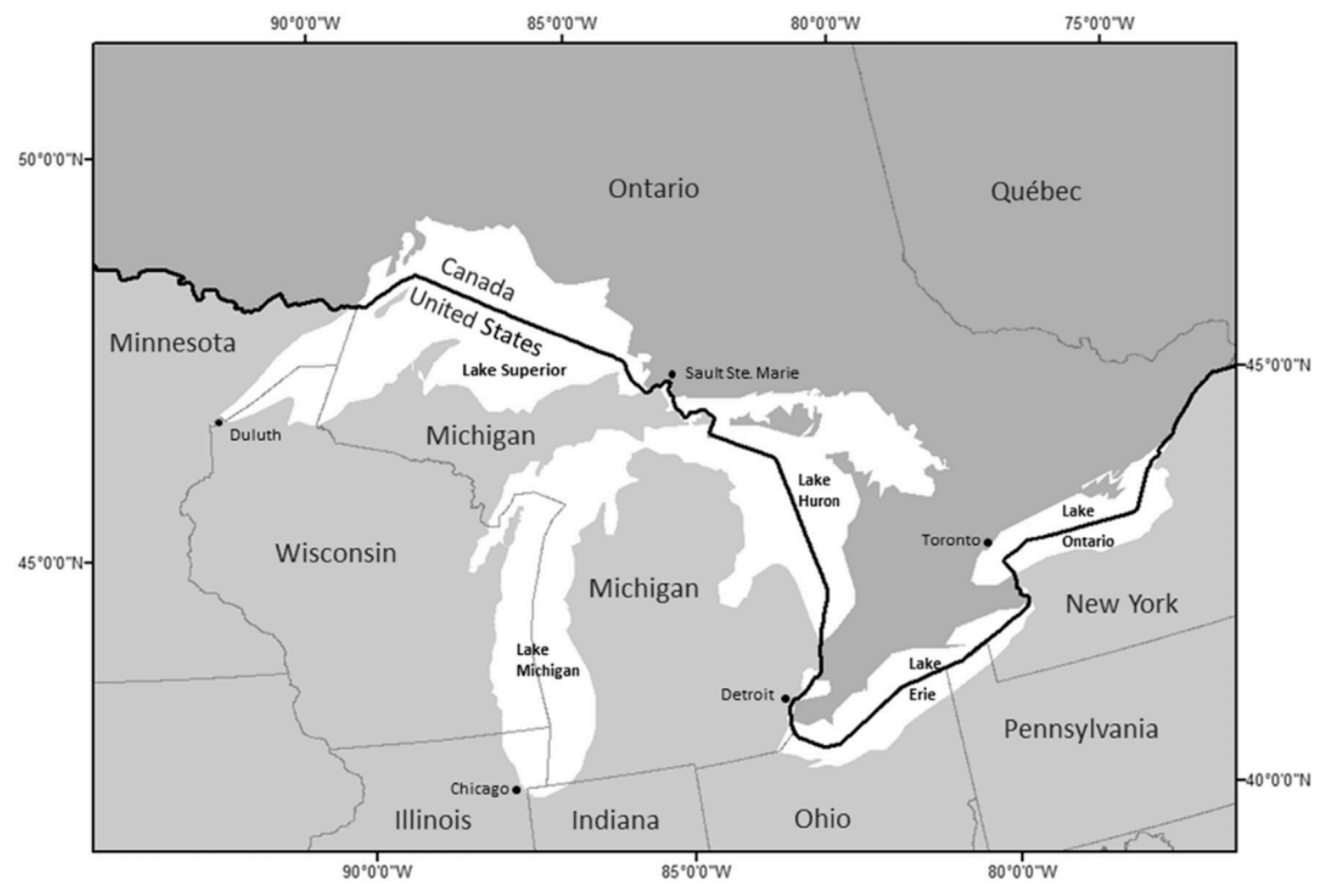

Fig. 1. Political boundaries and main cities in the Great Lakes region. 
More than 180 non-native aquatic organisms including plants, fish, algae and mollusks have become established in the Great Lakes in the past 200 years (Holeck et al., 2004; Ricciardi, 2006; Vander Zanden et al., 2010). With an increase in human activity in the watershed, the rate of introduction of exotic species has accelerated and more than one-third of non-native organisms have been introduced in the past 30 years alone (Great Lakes Information Network, 2016). Multiple invasive species such as zebra (Dreissena polymorpha) and quagga mussel (Dreissena rostriformis bugensis), round goby (Neogobius melanostomus), and sea lamprey (Petromyzon marinus) have generated severe impacts to the ecosystem in all five lakes leading to the loss of native species, alterations of food webs, and economic losses (Vander Zanden, 2008). Ballast water, release of non-native species from aquaria, building of canals, or stocking of non-native species in aquaculture operation are examples of pathways that have led to the introduction of non-native species in the Great Lakes basin (Holeck et al., 2004; Ricciardi, 2006). The pathways for introduction of pathogens remain unclear but their spread has also had critical consequences for the Great Lakes fishery (Wisconsin Sea Grant, 2013). The spread of viral hemorrhagic septicemia virus (VHS), for example, caused extensive losses of cultured and wild fish (Bain et al., 2010).

Boaters, anglers, and the bait industry are considered to be major contributors to the spread of pathogens and AIS (Vanderploeg et al., 2002; Rothlisberger et al., 2010; Kilian et al., 2012). Anglers and boaters can contribute to the spread in multiple ways. Examples include disposal of unused live bait that might be infected and/or include AIS or not cleaning boats and fishing equipment before moving it to another water (Litvak and Mandrak, 1993; Johnson et al., 2001; Rothlisberger et al., 2010; Kilian et al., 2012; Kelly et al., 2013). The bait industry potentially contributes to the spread by harvesting and selling wild bait from infested water bodies, or stock contamination in hatcheries (Goodchild, 2000; Faisal et al., 2012; Kilian et al., 2012). Reducing the spread by these groups on the scale of the Great Lakes system remains a major challenge given the large size of the basin and the many agencies involved in the management.

To understand management response taken to reduce further spread of pathogens and AIS in the Great Lakes recreational fishery, and to place human behaviors and management responses in the wider social-ecological context, we developed a conceptual model based on the DriversPressures-State-Impacts-Responses framework (DPSIR) (Fig. 2). We applied the framework since it allows for the integration of knowledge across disciplines in a systematic way (Kristensen, 2003; Martins et al., 2012; Tscherning et al., 2012). The DPSIR framework was originally developed in the late 1990 with the aim of structuring and organizing environmental indicators in a way that is meaningful to decision makers (Smeets and Weterings, 1999; OECD, 2003). Over time, the scope of the framework has been expanded to illustrate cause-effect relationships between natural and human systems to policy and decision-makers (Tscherning et al., 2012). Drivers in the framework (D) typically include human activities or environmental changes that put pressure on the environment $(P)$ and change the quantity and quality of resources and the environment $(S)$ that result in impacts $(I)$ that evoke management responses (R). 
The application of the framework to fisheries management is still novel (Martins et al., 2012). Previous studies used the framework to investigate overfishing and destructive fishing gear in coral reef systems (Mangi et al., 2007), to conduct a socio-economic analysis of multi-species fisheries in the North East Atlantic (Turner et al., 2010), and to identify drivers for fishing pressures (Knudsen et al., 2010). To our knowledge, no study has applied the framework to identify cause-effect relationships between human behaviors and the spread of pathogens and AIS in fisheries.

Another novelty of our study is the integration of managers' input for identifying socialecological linkages using the DPSIR framework. Most previous studies did not include natural resource managers in the conceptual development of the DPSIR framework even though the framework is frequently applied to provide information for managers and decision-makers to evaluate and adapt management actions (Tscherning et al., 2012). Our study therefore applies a novel approach to identify social-ecological relationships, and provides new insights into the opinions of managers on the spread of pathogens and AIS. At the same time, our study only explores opinions of agencies and organizations. Future studies could add to these insights and investigate the views of other stakeholder groups (e.g. bait dealers, angler, or boaters) to gain a broader understanding of the issue.

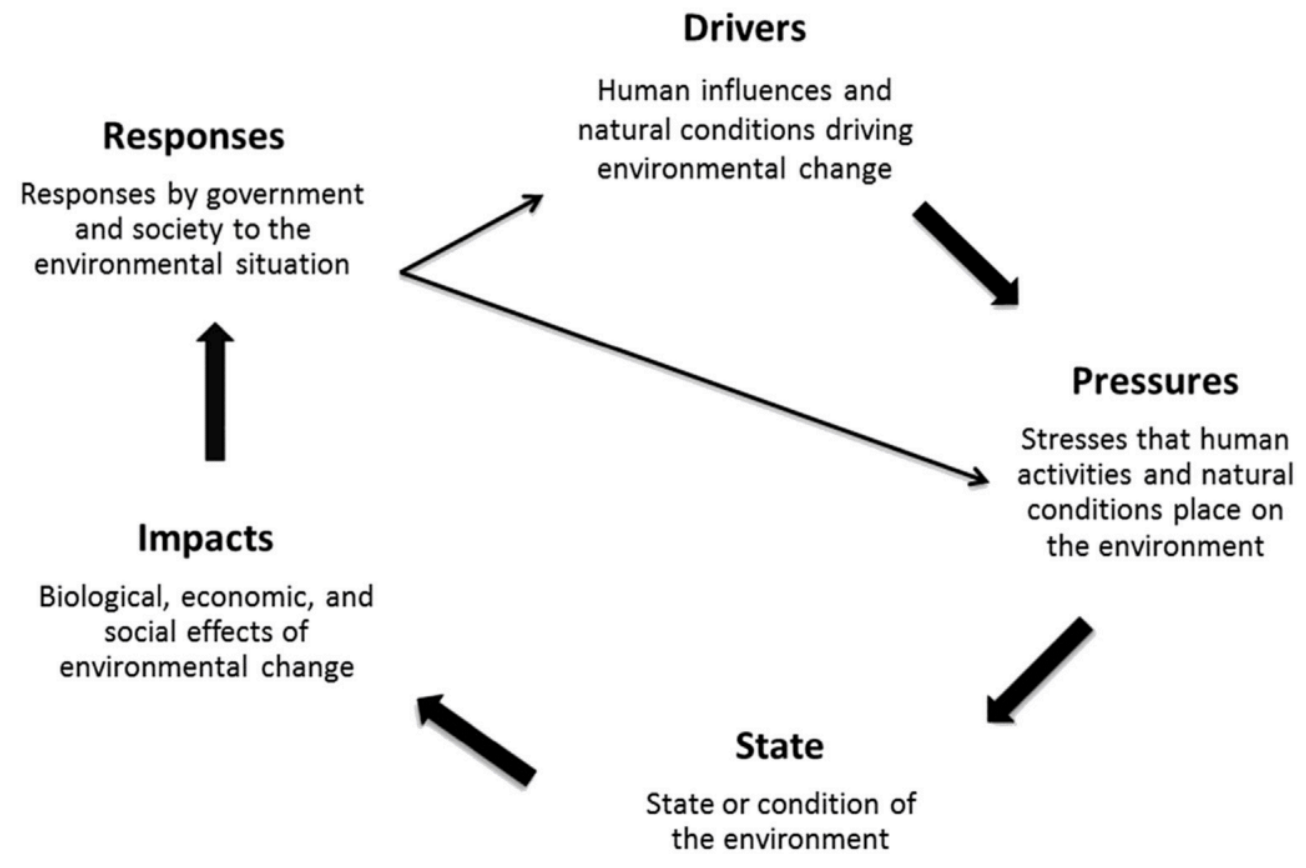

Fig. 2. Conceptual Drivers-Pressures-State-Impacts-Responses (DPSIR) model. Source: adapted after Walmsley (2009)

\section{Methods}

We conducted 43 semi-structured, open-ended telephone interviews between May-July 2012 with staff in governmental and non-governmental agencies and organizations in the United States and Canada who are involved in the management of pathogens and AIS in the Great Lakes fishery (Table 1). We included representatives of a variety of agencies and organizations 
to gain a more comprehensive understanding of the impacts of pathogens and AIS on the fishery and the management responses taken to reduce the spread. Participants were selected from state and provincial agencies, Sea Grants, the National Oceanic and Atmospheric Administration (NOAA), United States Department of Agriculture Animal and Plant Health Inspection Service (USDA-APHIS), the United States Fish and Wildlife Service (USFWS), Transport Canada, and Fisheries and Oceans Canada.

All interviewees had experience in working to reduce the spread of fish pathogens and AIS in the Great Lakes region through regulations and education. Respondents from government agencies were involved in the management and regulation of fisheries. Federal agencies play a minor role in the management of pathogens and AIS (e.g., import and interstate movement of VHS-susceptible species of live fish). The majority of regulations are implemented by state and provincial agencies that also engage in education efforts. Sea Grants and NGO respondents are only involved in education efforts as they have no regulatory authority. Interviewees were identified through recommendations of staff in the Great Lakes Fishery Commission and researchers with experience in the region. Interviews lasted between 30 and $60 \mathrm{~min}$. We used a semistructured interview guide to ensure that all interviewees answered the same general set of questions while still allowing respondents to express their unique perspectives. Interviewees were asked to respond on behalf of their institutions and to share information on (1) the perceived contribution of anglers, boaters, and bait dealers to the spread of pathogens and AIS; (2) perceived subsequent impacts on the Great Lakes fishery; and (3) and measures implemented by their agency to reduce further spread in the basin. With the consent of participants, interviews were audio recorded and transcribed. We analyzed the transcripts using computer software (Atlas.ti) designed to assist in the analysis of qualitative data. Responses were coded for the following themes: behaviors that contribute to the spread of pathogens and AIS; perceived subsequent changes in the ecosystem and impacts on the Great Lakes fishery; and implemented regulatory and educational management responses. Findings were categorized into the five stages of the DPSIR framework.

\begin{tabular}{|c|c|c|c|c|}
\hline Organization category & Types of organization & Country & Number of interviewees & Number of survey respondents \\
\hline \multirow[t]{3}{*}{ NGOs and Sea Grant } & NGOs & US & 2 & 4 \\
\hline & NGOs & $\mathrm{CA}$ & 2 & 1 \\
\hline & Sea Grants & US & 11 & 14 \\
\hline \multirow[t]{4}{*}{ Government agencies } & Federal & CA & 2 & 3 \\
\hline & Federal & US & 5 & 3 \\
\hline & State & US & 16 & 13 \\
\hline & Provincial & $\mathrm{CA}$ & 4 & 6 \\
\hline
\end{tabular}

The conducted interviews were an important first step to develop our model. We also implemented a follow up online survey between September-October 2012 to gain quantitative insights on the perceived contribution of different groups to the spread, to evaluate the implementation of mentioned regulations across all agencies, and to assess how frequently educational activities have been implemented. The survey was administered among the same agencies and organizations that we included in our interviews (Table 1). Survey participants consisted of interviewees and additional staff members based on interviewees suggestions. Out 
of 57 people that we contacted, 44 completed the survey (77.2\% response rate). The survey was implemented online using Qualtrics, a web based survey software. Individuals were invited via email to take part in the survey with a link to the survey provided. Individuals who did not respond to the first invitation received up to four additional requests to complete the survey. The survey contained closed questions asking about the existence of a variety of regulations that were mentioned in the previously conducted interviews and how frequently listed educational activities had been implemented in the five years prior to our study on a 4-point scale ranging from "never" to "every year." In addition, we asked about the perceived contribution of multiple variables to the spread of pathogens and AIS on a 5-point scale ranging from $0 \frac{1}{4}$ no contribution to $4 \frac{1}{4}$ very large contribution. Survey findings were analyzed using SPSS 15.

\section{Results}

Based on the analysis of our interviews and the categorization of findings into the stages of the DPSIR framework, we identified multiple social-ecological relationships key to the management of pathogens and AIS. (Fig. 3). The subsequent paragraphs describe the distinct stages in more detail from the perspective of our interviewees and survey respondents.

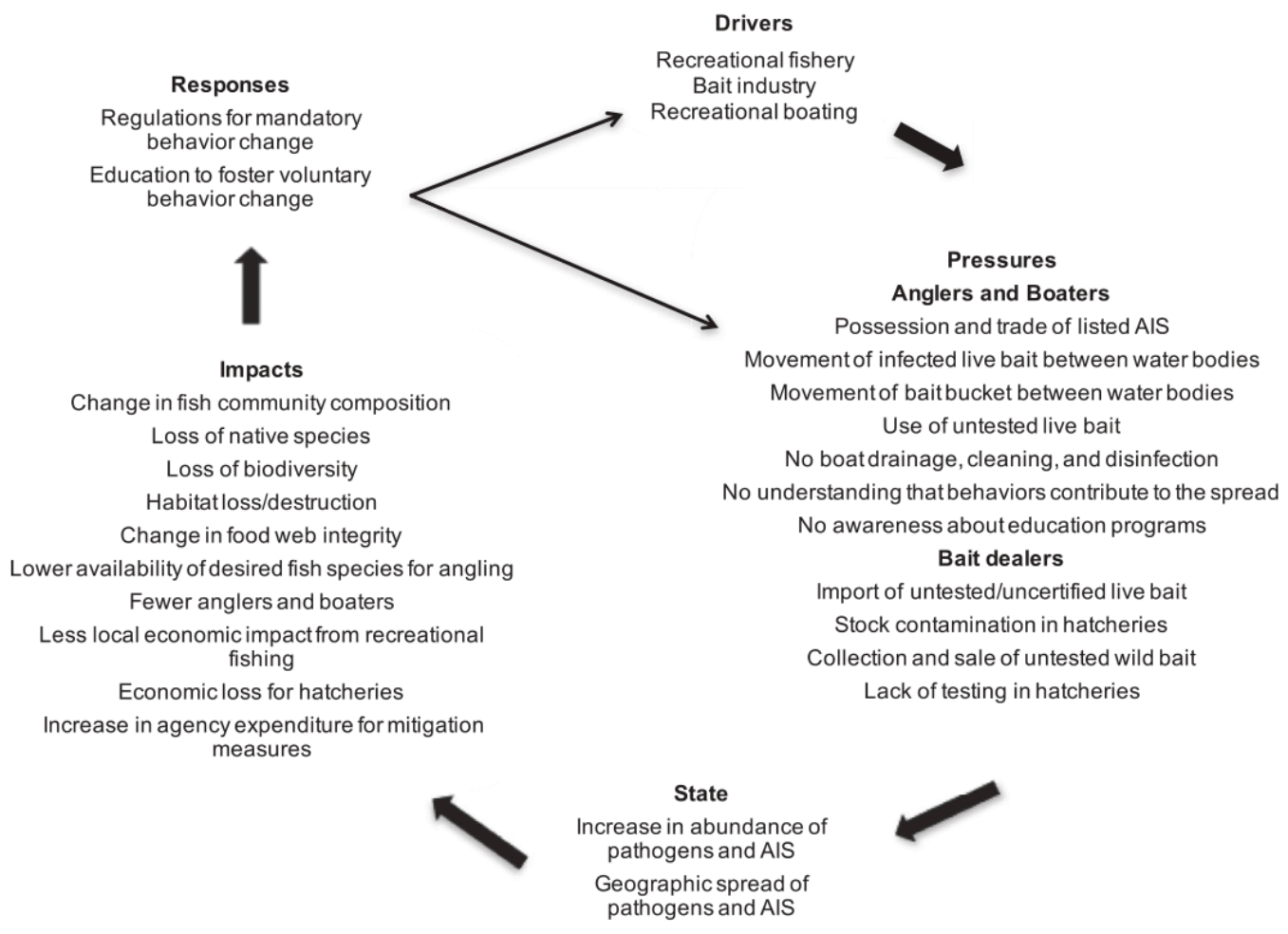

Fig. 3. The application of the DPSIR framework to the spread of pathogens and AIS by anglers, boaters, and bait dealers in the Great Lakes basin.

\subsection{Drivers and pressures}

Recreational fishing and boating in the Great Lakes has a long tradition and is economically and culturally important for communities in the basin. Recreational angling also sustains the 
regional bait industry that supplies live bait collected in the wild, raised in hatcheries, and/or imported from other states or countries.

All agencies and organizations perceived anglers and boaters to contribute more to the spread than bait dealers (Fig. 4) and identified a greater number of behaviors among anglers and boaters that contribute to the spread in the basin compared to bait dealers (Fig. 3).

Anglers and boaters were perceived to contribute to the spread in multiple ways including the movement of infected live bait between water bodies, insufficient boat drainage, cleaning, and disinfection before moving boats, and possession and trade of listed AIS. Interviewees suspected that these behaviors derived, to some extent, from a lack of awareness and knowledge about the issue. They mentioned that some anglers and boaters might not know that their behaviors contribute to the spread or might not recognize infected or alien species and move them inadvertently to another water body since these "fishes might look healthy to them so they are gonna move them." At the same time, interviewees also mentioned that some anglers and boaters "just don't care" and might have no intention to change their behavior even if their behaviors have negative consequences for the ecosystem and the fishery.

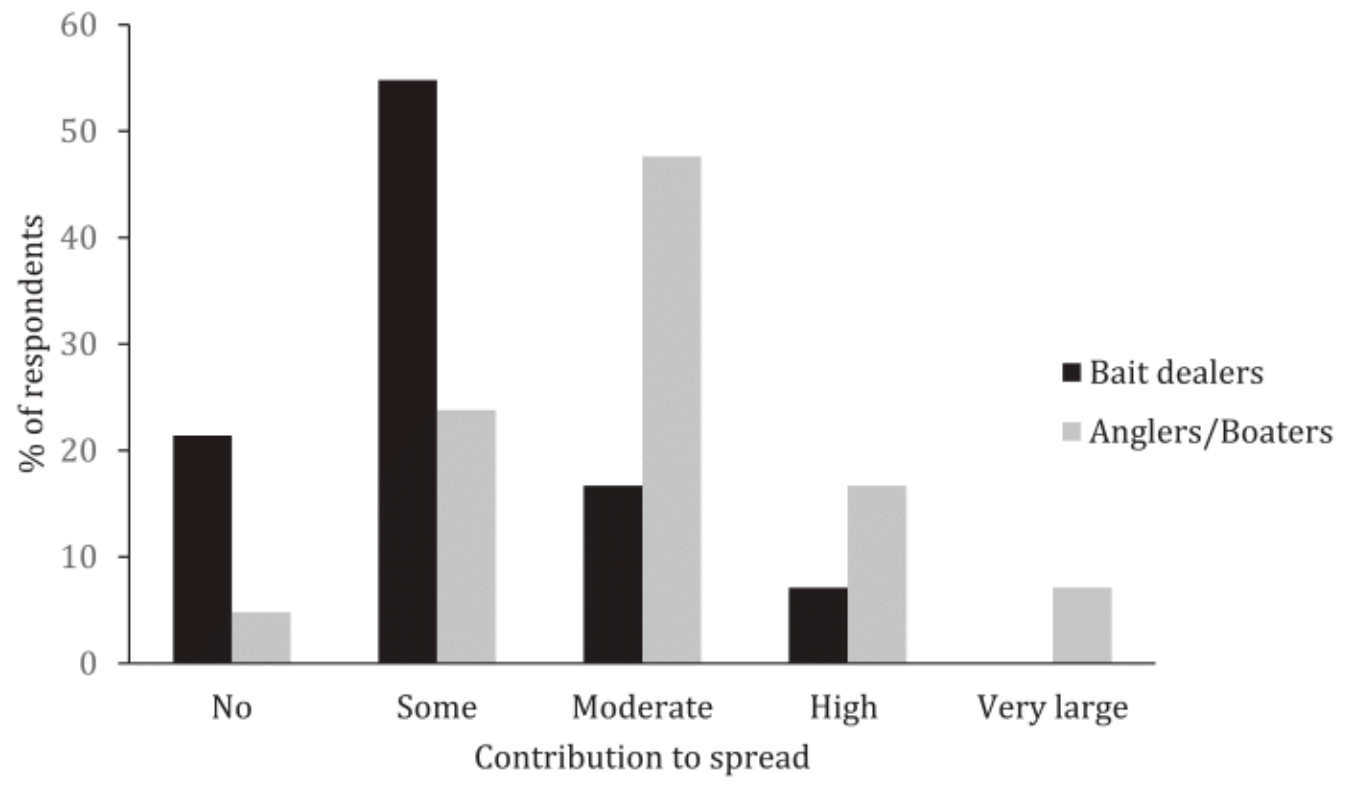

Fig. 4. Perceived contribution to spread (\% of survey respondents, $N=43$ ).

The contribution of bait dealers to the spread referred to trade of live baitfish across state lines that could contain alien invasive species, or may not have been tested for pathogens, and the collection of potentially infected or alien wild bait. Interviewees suspected that some bait dealers choose to ignore existing bait regulations and recommendations.

\subsection{State and impacts}

Interviewees believed that the continued infection of new water bodies led to an increase in the abundance and geographical spread of fish pathogens and AIS. This spread and subsequent changes in the ecosystem are perceived to have caused a variety of environmental, social, and 
economic impacts to the fishery (Fig. 5). Cited environmental impacts included loss of individual fish species, competition between native and non-native species, disruptions of existing food webs, and impacts on habitats and biodiversity. Interviewed managers also identified multiple economic and social impacts including economic losses for hatcheries because of fish kills caused by pathogens and consequently fewer fish available for recreational fisheries that rely on stocked fish species (especially the popular Pacific salmonids). These impacts would in turn reduce the number of recreational anglers and subsequently their spending patterns.

Respondents also maintained that financial costs for fishery management agencies would increase due to expenditures for mitigating measures (e.g., physical barriers or pheromonebased control for sea lampreys). Overall, anticipated impacts illustrate the close relationship between social, economic, and ecological impacts within the fishery. Ultimately, the mitigation of pathogens and AIS would reduce not only ecological impacts but also associated social and economic effects and possibly improve the overall sustainability of the fishery.

\subsection{Responses targeting anglers and boaters}

Management responses targeted towards anglers and boaters relied on a mix of education and regulations (Table 2). These efforts were undertaken by government agencies, NGOs, and Sea Grant and focused on providing information on recommended behaviors to prevent the spread, and implications of inadequate behaviors for the continued spread and subsequent impacts to the ecosystem and the fishery. Interviewees believed that providing information about environmental impacts would increase awareness of the need to change behaviors that contribute to the spread and foster desired behaviors.

A number of states also had implemented regulations for anglers and boaters (Table 2). These regulations mandate that anglers drain bait buckets before leaving a water body and clean and disinfect boats, equipment, and boatlifts before moving them between water bodies. Regulations, however, were not consistently applied across entire lakes as only a few states regulation for anglers and boaters in place at the time of our study. As multiple states are involved in the management of individual water bodies in the basin, regulatory management responses in particular were not adopted across entire lakes. Ontario seemed to have the lowest number of management responses in place and only focused on education. The province also did not use campaigns such as "Stop Aquatic Hitchhikers" and "Habitattitude" that have been adopted in the US to increase consistency of educational messages and to reduce confusion about messages to anglers and boaters that are visiting the Great Lakes from regions outside the basin.

\subsection{Responses targeting bait dealers}

Management responses targeting bait dealers primarily consisted of regulations (Table 3 ). Similar regulations have been applied fairly consistently across all states and Ontario with the exception of import and export regulations and regulations on the collection of wild bait. 
Education for bait dealers focused on the HACCP (Hazard Analysis Critical Control Point) protocol. The HACCP protocol is a self-inspection system for reducing the risk of spreading AIS through hatcheries and baitfish harvesting activities. The protocol has been implemented to help hatchery owners to maintain healthy stock and to prevent a "shut down" of hatcheries because of stock contamination. The HACCP protocol guidelines have been distributed by Sea Grants in workshops for hatchery operators and bait harvesters to increase understanding of the protocol and to demonstrate its principles. These efforts, however, were not frequently applied across jurisdictions in the five years prior to our study suggesting that they only played a minor role in the set of management responses to reduce the spread by bait dealers.

Table 2

Management responses for anglers and boaters in each state and Ontario at the time of our study.

\begin{tabular}{l}
\hline Education ${ }^{\mathrm{a}}$ \\
How to prevent spread of pathogens and AIS \\
Possible implications of movement of live bait
\end{tabular}

Table 3

Management responses for bait dealers in each state and Ontario at the time of our study.

\begin{tabular}{|c|c|c|c|c|c|c|c|c|c|}
\hline & \multicolumn{9}{|c|}{ States and provinces ${ }^{d}$} \\
\hline & $\mathrm{IL}$ & IN & MI & MN & NY & $\mathrm{OH}$ & ON & PA & WI \\
\hline \multicolumn{10}{|l|}{ Regulations $^{\mathrm{a}}$} \\
\hline No movement of bait out of VHS zone & * & & * & * & * & - & * & * & * \\
\hline VHS testing before bait is imported & $*$ & & * & * & * & - & & * & * \\
\hline VHS testing before bait can be sold & * & & * & * & * & - & & $*$ & \\
\hline No possession and trade of listed AIS as bait & * & * & * & * & * & - & * & & * \\
\hline Bait certification & * & & * & * & * & - & & & * \\
\hline No import of live bait from other states to use in your state & & & * & * & & - & * & & \\
\hline No import of live bait from other states to export to other states & & & * & * & & - & * & & \\
\hline No sale of wild fish bait that is not tested & * & & & & $*$ & - & & & * \\
\hline \multicolumn{10}{|l|}{ Education } \\
\hline Pathogen testing/HACCP ${ }^{c}$ procedures & & & & & & & & & \\
\hline
\end{tabular}




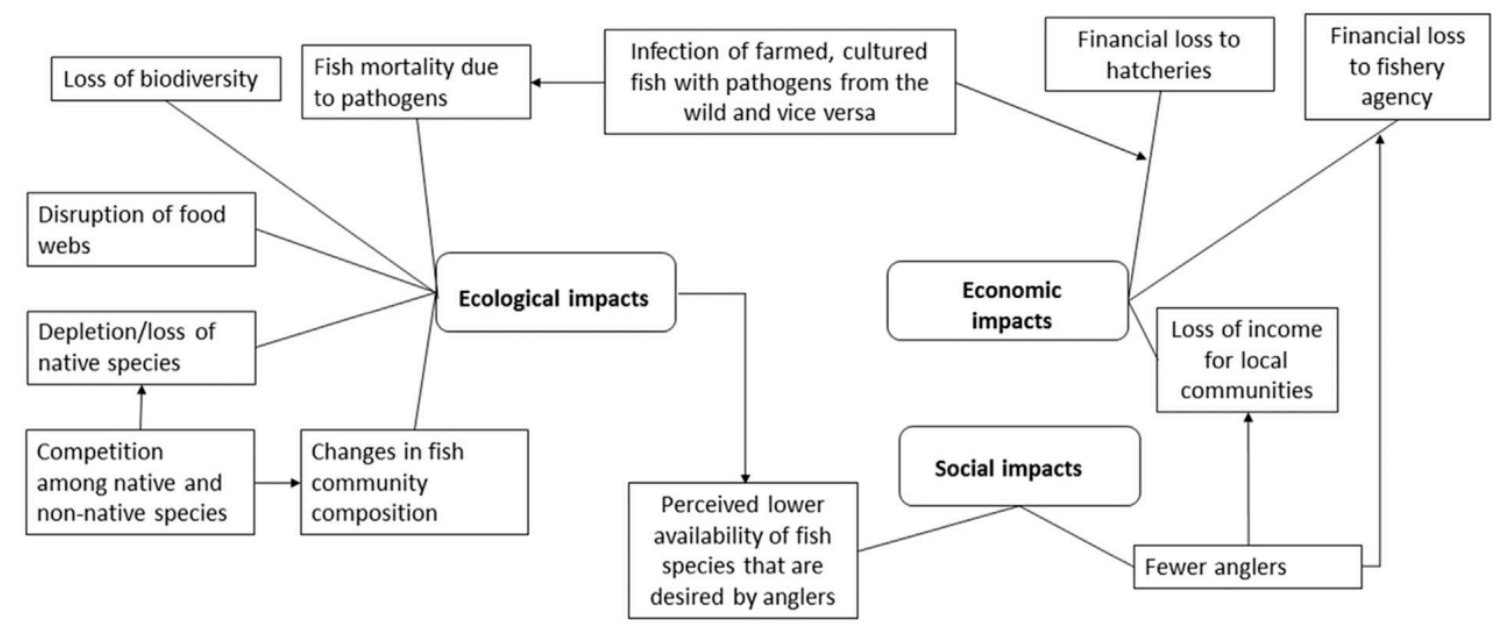

Fig. 5. Interviewees' perceptions of impacts on the Great Lakes fishery due to the spread of pathogens and AIS.

\section{Discussion}

Our study applied the DPSIR framework to conceptualize relationships between behaviors of bait dealers and recreational users, the spread of pathogens and AIS, and management responses. This conceptualization was based on the input of staff in governmental agencies and non-governmental organizations to understand the views of these relatively under-studied groups on the spread, and to apply a novel approach to the development of the DPSIR framework. The input of a variety of agencies and organizations allowed for a more comprehensive understanding of the different stages in the model as all respondents contributed insights based on their unique involvement in the management of pathogens and AIS. State and provincial agencies contributed the most diverse insights in the management response stage due to their engagement in both regulations and education. Sea Grants and NGO respondents offered additional insights on education efforts in the management response section. All respondents contributed to the pressure, state, and impact stages of the model.

Our model identified multiple relationships between human behaviors and the subsequent spread of pathogens and AIS. Respondents in our study felt that anglers and boaters currently contribute more to the spread of pathogens and AIS than bait dealers and listed multiple detrimental behaviors of these groups that add to the spread. Management responses to change these behaviors, and to reduce subsequent changes in the ecosystem and impacts on the fishery, included a mix of regulations and education. Both approaches pose distinct challenges. Achieving voluntary behavior changes among anglers and boaters is usually not an easy task and studies on this topic reported mixed findings. A study by Rothlisberger et al. (2010), for example, found that boaters in Wisconsin and Michigan did not follow recommendations to clean their boats and trailers despite great efforts in these states to educate these groups about appropriate behavior. Another study found that anglers and boaters choose to ignore recommendations if they did not perceive behavior change as necessary or considered it inconvenient (Kilian et al., 2012). A study by Connelly et al. (2016) 
however reported that anglers made substantial efforts to follow some recommendations including inspecting their equipment and draining water holding compartments before moving boats to a new water body. At the same time, the study found that compliance with actions that require more equipment, money, or time (e.g. disinfecting and drying boats and equipment) was not very high. Social marketing research studies further argued that behavioral changes are unlikely if the behavior change does not provide apparent benefits or gratification to the individual (Mckenzie Mohr, 2000).

Since the spread of pathogens and AIS not only affects the ecosystem in the basin but also leads to social and economic impacts, as identified in our model, the continued spread could ultimately affect anglers and boaters and the quality of their experience. Emphasizing that behavior changes would prevent or at least mitigate these impacts could instill a notion of personal benefits from a reduced spread, and provide incentives for behavior changes. Our model could add to these education efforts as it provides critical information on the perceived connection between human behaviors and impacts on the fishery thereby explaining why behavior changes are needed. The model could also help to illustrate how anglers and boaters themselves might benefit if impacts on the fishery and ecosystem would be reduced.

A few states have also adopted regulations for anglers and boaters, which poses different challenges. Previous studies in fisheries, for example, found considerable non-compliance rates with regulations due to lack of knowledge and/or dissatisfaction with regulations (e.g. Schill and Kline, 1995; Pierce and Tomcko, 1998; Page and Radomski, 2006; Thomas et al., 2015). Anglers' and boaters' perception and knowledge of regulations could be critical to foster compliance with implemented regulations and to encourage behavior changes. Another challenge is the enforcement of regulations given the scale of the basin and the high number of boaters and anglers; there are more than 4.2 million small-craft boats in the eight US states bordering the Great Lakes and more than 2 million recreational boats on the Canadian side of the border (Thorp and Stone, 2000).

Difficulties in enforcing regulations across such a large geographical scale and community could be one of the reasons why most states focused more on education than regulation for anglers and boaters at the time of our study. As multiple states are involved in the management of individual water bodies in the basin, regulatory management responses in particular were not adopted across entire lakes. We also detected some differences between US and Canadian management responses. Ontario did not have any regulation in place for anglers and boaters and seemed to focus on education alone. The province also did not adopt campaigns such as "Stop Aquatic Hitchhikers" and "Habitattitude" that have been used in the US to increase consistency of educational messages and to reduce confusion about messages to anglers and boaters that are visiting the Great Lakes from regions outside the basin. This inconsistent adoption of management efforts could greatly reduce the effectiveness of management responses to reduce pressures identified in our model. Understanding which regulatory and voluntary measures are most effective to change behaviors and adopting the most effective means consistently across entire lakes could foster behavior changes across entire waterbodies. Addressing the spread of pathogens and AIS across entire lakes and/or the whole basin will be 
critical to reduce further spread as ecological processes typically do not conform to political boundaries (Crowder et al., 2006; Ekstrom and Young, 2009).

Management responses for bait dealers primarily centered on regulations and were fairly consistently adopted across all states and Ontario with few exceptions. As bait dealers are a smaller group compared to anglers and boaters, enforcing this group might be more feasible, which could be one reason for the emphasis on regulatory management responses.

Management agencies further thought that bait dealers did not contribute to the spread to the same degree as anglers and boaters. One explanation could be that bait dealers might be more knowledgeable and concerned about pathogens and AIS than anglers and boaters. A study by Connelly et al. (2014) on Lake Ontario, for example, found that almost all bait dealers had heard of pathogens and AIS and were concerned about their impacts on the health of fish populations in the region. Bait dealers, who have a vested economic interest in the health of the recreational fishery, therefore seem to be aware of the spread, behaviors that contribute to it, and subsequent impacts on the ecosystem and fishery. Bait dealers' level of knowledge could explain the lower emphasis placed by management agencies on education for this group as opposed to anglers and boaters who were seen to be lacking necessary knowledge and requiring more education on the topic. Connelly et al. (2014) further found that the majority of bait dealers were familiar with regulations and felt that following these regulations is important. Future studies could evaluate in how far bait dealers actually follow regulations, and to what extent bait dealers across the whole basin comply with implemented regulations to understand the effectiveness of taken management responses across the basin.

\section{Conclusions}

The spread of aquatic invasive species and pathogens in the Great Lakes remains a critical environmental problem that affects multiple sectors in the basin including fisheries.

The identified relationships in our research could serve as starting points for future research to investigate these linkages in more detail, and to provide empirical insights into the identified cause-effect relationships. Achieving behavior changes, for example, remains a major challenge for fishery management agencies. Understanding what kind of regulations and education efforts, including communication means, are most effective to achieve desired behavioral changes would help to prevent wasting valuable management resources on ineffective efforts. Such studies could differentiate between the effectiveness of actions taken by state, provincial, and federal agencies and NGOs and distinguish the contributions of different levels of government and types of organizations. Empirical data on the spatial spread of AIS and pathogens across the lakes and subsequent impacts on the Great Lakes ecosystem and fishery could help to predict and model spatial patterns of changes in the state and impacts stages.

Managers and outreach organizations (e.g., Sea Grant) could use our model to communicate social-ecological relationships. This kind of information could help raise awareness and understanding of the inter-relationship between human behaviors and the subsequent spread of pathogens and AIS, and demonstrate the necessity of particular management responses. 
Ideally, such an understanding would increase acceptance and support for voluntary and mandatory management measures, foster desired behavior changes, and ultimately reduce further spread in the basin and associates.

Our study only investigated views of staff in government agencies and NGOs/Sea Grants. Future studies could expand or replicate the model with input by other groups such as bait dealers and/or anglers and boaters. Assessing the opinions of these groups would provide multiple new insights. Incorporating the input of stakeholders would enable the development of a more comprehensive model that accounts for the perspective of multiple stakeholder groups. Comparing the views of stakeholders with the findings presented in this study would further help identify if these groups share an understanding of the social-ecological linkages identified by managers. Such information would be important as an understanding of these linkages might shape stakeholders' views on the efficacy and necessity of implemented management responses.

Future studies could also apply the framework to develop a similar model for other pressures (e.g., pet industry, shipping) that contribute to the continued spread of pathogens and AIS in the basin. Such models could be linked or combined with our model to understand cumulative impacts, and to enable ecosystem-based management that addresses multiple drivers and pressures.

\section{Acknowledgements}

The study was funded by the Great Lakes Fishery Commission.

\section{References}

Anderson, L.G., White, P.C.L., Stebbing, P.D., Stentiford, G.D., Dunn, A.M., 2014. Biosecurity and vector behaviour: evaluating the potential threat posed by anglers and canoeists as pathways for the spread of invasive non-native species and pathogens. PLoS ONE 9 (4), e92788.

Bain, M.B., Cornwell, E.R., Hope, K.M., Eckerlin, G.E., Casey, R.N., Groocock, G.H., Getchell, R.G., Bowser, P.R., Winton, J.R., Batts, W.N., Cangelosi, A., Casey, J.W., 2010. Distribution of an invasive aquatic pathogen (viral hemorrhagic septicemia virus) in the great lakes and its relationship to shipping. PLoS ONE 5 (4), e10156.

Connelly, N.A., Biedron, I.S., Lauber, T.B., 2014. Roles of Boating Facilities, Bait Dealers, and Angler and Boating Organizations in Preventing the Spread of Aquatic Invasive Species in the Lake Ontario Basin. HDRU Publ. No. 14e12. Dept. of Nat. Resour., Coll. Agric. and Life Sci., Cornell Univ., Ithaca, NY.

Connelly, N.A., Lauber, T.B., Stedman, R.C., Knuth, B.A., 2016. The role of anglers in preventing the spread of aquatic invasive species in the Great Lakes region. J. Gt. Lakes. Res. 42 (3), $703 e 707$. 
Crowder, L.B., Osherenko, G., Young, O.R., Airame, S., Norse, E.A., Baron, N., Day, J.C., Douvere, F., Ehler, C.N., Halpern, B.S., Langdon, S.J., 2006. Resolving mismatches in US ocean governance. Science 313 (5787), 617.

Ekstrom, J.A., Young, O.R., 2009. Evaluating functional fit between a set of institutions and an ecosystem. Ecol. Soc. 14 (2), 16.

Faisal, M., Shavalier, M., Kim, R.K., Millard, E.V., Gunn, M.R., Winters, A.D., Schulz, C.A., Eissa, A., Thomas, M.V., Wolgamood, M., Whelan, G.E., Winton, J., 2012. Spread of the emerging viral hemorrhagic septicemia virus strain, genotype IVb, in Michigan, USA. Viruses 4 (5), 734e760.

Gaden, M., Goddard, C.I., Read, J., 2012. A history of multi-jurisdictional management of the shared Great Lakes fishery: transcending conflict and diffuse political authority. In: Taylor, W., Lynch, A., Leonard, N. (Eds.), Great Lakes Fishery Management and Policy. Michigan University Press, East Lansing.

Goodchild, C.D., 2000. Ecological impacts of introductions associated with the use of live bait. In: Claudi, R., Leach, J. (Eds.), Nonindigenous Freshwater Organisms: Vectors, Biology, and Impacts. Lewis Publishers, Boca Raton, pp. 181e202.

Great Lakes Information Network, 2016. Invasive Species in the Great Lakes Region. Online available at: http://www.great-lakes.net/envt/flora-fauna/invasive/invasive.html (accessed 07.07.16.).

Holeck, K.T., Mills, E.L., Macisaac, H.J., Dochoda, M.R., Colautti, R.I., Ricciardi, A., 2004. Bridging troubled waters: biological invasions, transoceanic shipping, and the laurentian great lakes. BioScience 54 (10), 919e929.

Jacobs, M., Macisaac, H., 2007. Fouling of fishing line by the waterflea Cercopagis pengoi: a mechanism of human-mediated dispersal of zooplankton? Hydrobiologia 583 (1), 119e126.

Johnson, L.E., Ricciardi, A., Carlton, J.T., 2001. Overland dispersal of aquatic invasive species: a risk assessment of transient recreational boating. Ecol. Appl. 11 (6), 1789e1799.

Kelly, N., Wantola, K., Weisz, E., Yan, N., 2013. Recreational boats as a vector of secondary spread for aquatic invasive species and native crustacean zooplankton. Biol. Invasions 15 (3), $509 \mathrm{e} 519$.

Kilian, J., Klauda, R., Widman, S., Kashiwagi, M., Bourquin, R., Weglein, S., Schuster, J., 2012. An assessment of a bait industry and angler behavior as a vector of invasive species. Biol. Invasions 14 (7), 1469e1481. 
Knudsen, S., Zengin, M., Koçak, M.H., 2010. Identifying drivers for fishing pressure. A multidisciplinary study of trawl and sea snail fisheries in Samsun, Black Sea coast of Turkey. Ocean Coast. Manag. 53 (5e6), 252e269.

Kristensen, P., 2003. EEA Core Set of Indicators. Revised Version April 2003. Adopted Version for ECCAA Countries May 2003. European Environment Agency.

Litvak, M.K., Mandrak, N.E., 1993. Ecology of freshwater baitfish use in Canada and the United States. Fisheries 18 (12), 6e13.

Lodge, D.M., Williams, S., Macisaac, H.J., Hayes, K.R., Leung, B., Reichard, S., Mack, R.N., Moyle, P.B., Smith, M., Andow, D.A., Carlton, J.T., Mcmichael, A., 2006. Biological invasions: recommendations for U.S. Policy and management. Ecol. Appl. 16 (6), 2035e2054.

Mangi, S.C., Roberts, C.M., Rodwell, L.D., 2007. Reef fisheries management in Kenya: preliminary approach using the driverepressureestateeimpactseresponse (DPSIR) scheme of indicators. Ocean Coast. Manag. 50 (5e6), 463e480.

Martins, J.H., Camanho, A.S., Gaspar, M.B., 2012. A review of the application of driving forcespressure-State-impact-Response framework to fisheries management. Ocean Coast. Manag. 69 (0), $273 e 281$.

Mckenzie-Mohr, D., 2000. New ways to promote proenvironmental behavior: promoting sustainable behavior: an introduction to community-based social marketing. J. Soc. Issues 56 (3), $543 e 554$.

Myers, N., Knoll, A.H., 2001. The biotic crisis and the future of evolution. Proc. Natl. Acad. Sci. 98 (10), 5389e5392.

OECD, 2003. Environmental Indicators e Development, Measurement and Use. Organisation of Economic Co-operation and Development.

Oidtmann, B.C., Thrush, M.A., Denham, K.L., Peeler, E.J., 2011. International and national biosecurity strategies in aquatic animal health. Aquaculture 320 (1e2), 22e33.

Olden, J.D., Leroy Poff, N., Douglas, M.R., Douglas, M.E., Fausch, K.D., 2004. Ecological and evolutionary consequences of biotic homogenization. Trends Ecol. Evol. 19 (1), $18 \mathrm{e} 24$.

Page, K.S., Radomski, P., 2006. Compliance with sport fishery regulations in Minnesota as related to regulation awareness. Fisheries 31 (4), $166 \mathrm{e} 178$.

Pierce, R.B., Tomcko, C.M., 1998. Angler noncompliance with slot length limits for northern pike in five small Minnesota lakes. North Am. J. Fish. Manag. 18 (3), $720 \mathrm{e} 724$. 
Rahel, F.J., 2007. Biogeographic barriers, connectivity and homogenization of freshwater faunas: it's a small world after all. Freshw. Biol. 52 (4), $696 \mathrm{e} 710$.

Ricciardi, A., 2006. Patterns of invasion in the Laurentian Great Lakes in relation to changes in vector activity. Divers. Distrib. 12 (4), 425e433.

Rothlisberger, J.D., Chadderton, W.L., Mcnulty, J., Lodge, D.M., 2010. Aquatic invasive species Transport via trailered boats: what is being moved, who is moving it, and what can Be done. Fisheries 35 (3), 121e132.

Sala, O.E., Stuart Chapin, F., Armesto, J.J., Berlow, E., Bloomfield, J., Dirzo, R., HuberSanwald, E., Huenneke, L.F., Jackson, R.B., Kinzig, A., Leemans, R., Lodge, D.M., Mooney, H.A., Oesterheld, M.N., Poff, N.L., Sykes, M.T., Walker, B.H., Walker, M., Wall, D.H., 2000. Global biodiversity scenarios for the year 2100. Science 287 (5459), 1770e1774.

Schill, D.I., Kline, P.A., 1995. Use of random response to estimate angler noncompliance with fishing regulations. North Am. J. Fish. Manag. 15 (4), 721e731.

Smeets, E., Weterings, R., 1999. Environmental Indicators: Typology and Overview. European Environment Agency, Copenhagen.

Strayer, D., Findlay, S.G., 2010. Ecology of freshwater shore zones. Aquat. Sci. 72 (2), 127e163.

Thomas, A.S., Milfont, T.L., Gavin, M.C., 2015. What determines fishers' knowledge of and attitudes towards regulations? A case study from the Marlborough Sounds, New Zealand. Mar. Policy $51(0), 547 e 554$.

Thorp, S., Stone, J., 2000. Recreational Boating and the Great LakeseSt. Lawrence Region. Great Lakes Commission, Ann Arbor, Michigan.

Tscherning, K., Helming, K., Krippner, B., Sieber, S., Paloma, S.G.Y., 2012. Does research applying the DPSIR framework support decision making? Land Use Policy 29 (1), 102e110.

Turner, R.K., Hadley, D., Luisetti, T., Lam, V., Cheung, W., 2010. An Introduction to Socioeconomic Assessment within a Marine Strategy Framework. CSERGE: University of East Anglia.

Vander Zanden, M., 2008. Surveillance and control of aquatic invasive apecies in the Great Lakes. In: The St Lawrence Seaway: Options to Eliminate Introductions of Aquatic Invasice Species in the Great Lakes. Transportation Research Board.

Vander Zanden, M.J., Hansen, G.J.A., Higgins, S.N., Kornis, M.S., 2010. A pound of prevention, plus a pound of cure: early detection and eradication of invasive species in the laurentian great lakes. J. Gt. Lakes. Res. 36 (1), $199 e 205$. 
Vanderploeg, H.A., Nalepa, T.F., Jude, D.J., Mills, E.L., Holeck, K.T., Liebig, J.R., Grigorovich, I.A., Ojaveer, H., 2002. Dispersal and emerging ecological impacts of ponto-caspian species in the laurentian great lakes. Can. J. Fish. Aquat. Sci. 59 (7), $1209 \mathrm{e} 1228$.

Walmsley, J., 2009. Gulf of Maine State of the Environment Reporting. Fisheries and Oceans Canada.

Wisconsin Sea Grant, 2013. VHS in the Great Lakes Fish. Online available at: http:// www.seagrant.wisc.edu/home/Default.aspx?tabid $1 / 4531$ (accessed 07.07.16.). 